vertical posture. But unless such traits improve the fitness of both males and females (in which case natural selection alone can do the job), sexual selection will produce differences between the sexes, as it probably did with human body size. Why, then, don't we see knuckle-walking women with chimpanzee-sized brains? Although we may never know why humans became erect and brainy, sexual selection seems among the least plausible of many alternative theories.

Despite its considerable merits, The Ancestor's Tale seems the least compelling of
Dawkins' works. Given the author's talents, however, this may be akin to judging Coriolanus Shakespeare's least compelling play. Thankfully, Dawkins returns to top form in the final chapter, a philosophical overview of the extraordinary events he's just recounted. Here he grapples with questions of whether evolution would produce similar creatures if it began anew (a qualified yes), and whether evolution itself promotes "evolvability", making species even more likely to respond to future selection (another qualified yes).

His final sentences are quintessential
Dawkins, with language at its most lambent and elegant, used simply to express profound truths: "The fact that life evolved out of nearly nothing ... is a fact so staggering that I would be mad to attempt words to do it justice. And even that is not the end of the matter. Not only did evolution happen: it eventually led to beings capable of comprehending the process, and even of comprehending the process by which they comprehend it."

Jerry A. Coyne is in the Department of Ecology and Evolution, University of Chicago, Chicago, Illinois 60637, USA.

\section{First steps in science}

\section{Curious Minds: How a Child \\ Becomes a Scientist \\ edited by John Brockman \\ Pantheon: 2004. 256 pp. \$23.95, £16.99 \\ Paul L. Harris}

John Brockman asked 27 distinguished scientists from diverse fields, including physics, psychology, biology, mathematics and robotics, to write a short biographical sketch, describing their childhood and what got them hooked on science. The heterogeneity of the essays they wrote serves as an antidote to easy speculation about there being any essential precursors to scientific accomplishment.

Is a scientifically oriented family important? It looks that way at first as you read through the opening piece by psychologist Nick Humphrey. One of his early memories - vividly described - is of being taken by his grandfather on Boxing Day to dissect a frog in the empty, silent anatomy department of University College, London. The grandfather, as it happens, has a Nobel prize in physiology, and is just one family figure in a distinguished panoply. Humphrey candidly writes: "What I gained from this childhood environment was a sense of intellectual entitlement — a right to ask questions, to pry, to provoke, to go where I pleased in pursuit of knowledge."

That sense of intellectual entitlement is echoed by cognitive scientist Alison Gopnik. She writes of her parents' devotion to their children's intellectual lives, not with a view to "enrichment" or "achievement", but with a gift for making such intellectual activity "the accepted, ordinary, happy way that civilized people went about their lives". Ray Kurzweil, an inventor, recalls a similarly intense intellectual life in his family circle: "The intense and animated discussions were invariably about new ideas, usually those of intellectuals I had never heard of. The way for me to get attention was to have an idea."

But consider, by contrast, the childhood

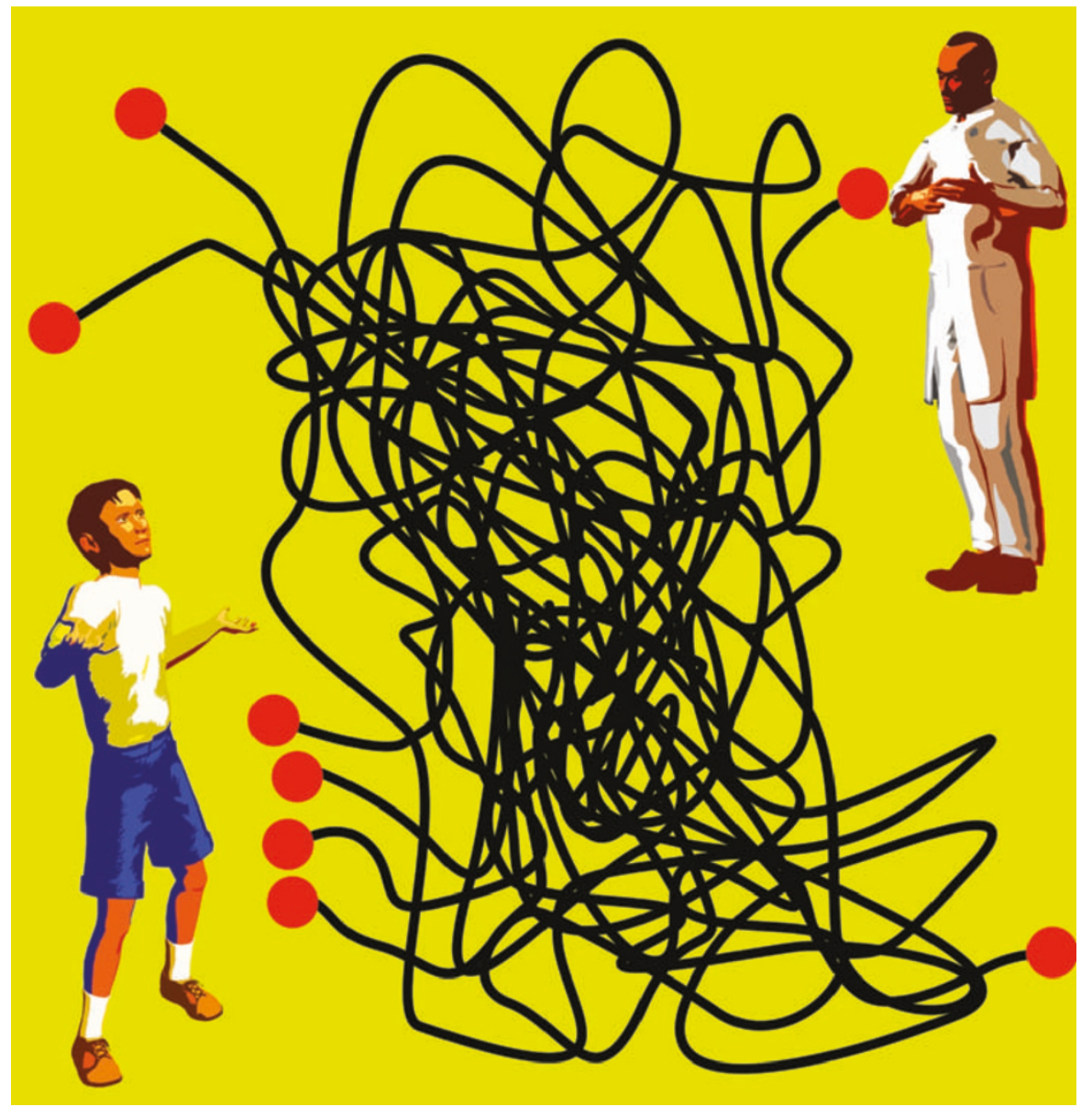

of the computer scientist Jaron Lanier. His mother died when he was nine and he was raised by an indigent father with an interest in psychic phenomena. For a while they lived in tents in southern New Mexico before moving into a fragile geodesic dome designed by his father. Such an eccentric upbringing might nurture intellectual independence, but it's a long way from the scientific dynasty described by Humphrey or the high-minded but nurturing family in which Gopnik was raised. Neuroscientist Joseph LeDoux describes an equally unpropitious start. His father was a bull rider in the rodeo and hoped that his only child would emulatehim.

Another plausible candidate for later scientific accomplishment is a keen childhood interest in some branch of the natural world: insects, stars, fossils or electricity. Some contributors do display such a passion. Computer scientist Rodney Brooks, for example, was already fascinated by electric circuits at the age of seven. And Lynn Margulis, a biologist, writes of lying on her belly to watch ant colonies. Yet there are disconcerting exceptions. Another biologist, Richard Dawkins, tells an amusing story about mistaking a blue tit for a chaffinch. Shocked at the boy's error, his grandfather turned to Dawkins' father and remonstrated: "Good God, John —is that possible?"

The conclusion that does emerge from this collection is that a huge number of different paths lead to a successful scientific career. Some can be tentatively traced back 
to early childhood, but others receive a bump start later in life from a mentor or teacher, and many illustrate how chance encounters provoke a dramatic new direction. Without providing any general conclusions, these essays offer the idiosyncrasy and curiosity value that we expect of good, narrative history, combined with much fine writing.

Two contributors - Stephen Pinker and Judith Harris - adopt a scientistic stance toward the whole narrative enterprise. Don't trust our childhood recollections, they caution, and certainly beware of any causal connections that we infer. Psychological research on the unreliability of childhood memories and our frequent lack of introspective access to potent influences on our choices lend weight to their cautionary remarks. But few readers will feel comfortable reading these accounts so sceptically. Many of the contributors revisit their childhood with gusto - and with palpable curiosity. What they write is quirky, absorbing and persuasive in just the way that good stories are.

Paul L. Harris is at the Harvard Graduate School of Education, 503A Larsen Hall, Appian Way, Cambridge, Massachusetts 02138, USA.

\section{Stalking life's second secret}

The Proteus Effect: Stem Cells and their Promise for Medicine by Ann B. Parson

Joseph Henry Press: 2004. 304 pp. \$24.95

\section{Lee M. Silver}

On 28 February 1953, Francis Crick famously burst into a Cambridge pub with Jim Watson in tow and exclaimed triumphantly: "We have found the secret of life!" The rest, as the cliché goes, is history. Both scholarly and popular accounts of the personalities and events surrounding the discovery of the double helix, and subsequent advances in molecular genetics, have appeared in tens of thousands of books and articles. The DNA story is taught in school biology classes to eight-year-old children. Several DNA-based Nobel prizes have already been won, and more are no doubt waiting in the wings.

Genes and genomes, however, represent only one of two pillars of likely twenty-firstcentury progress in biomedicine. The second is stem-cell biology. And yet, while everyone knows of Watson and Crick, hardly anyone has heard of Leroy Stevens and other early stem-cell pioneers. Indeed, many scientists are unaware of the five decades of advances that occurred before the 1998 isolation of human embryonic stem cells. In her new book The Proteus Effect, journalist Ann
Parson fills the gap with a breezy, easily accessible narrative of the people, results and ideas that have shaped the field.

Parson traces the birth of modern stem-cell research back to 1953, the same year that the double helix made its debut. Although the means for composing and reproducing life's genetic recipes had been a fundamental secret of life, it was not the only one. A second mystery was the process by which a microscopic embryo could develop into a fully functional human being or other mammal. Embryologists knew that development occurred through the controlled growth, division and specialization of individual cells, but they didn't know how developmental control was asserted. Many assumed, without evidence, that a permanent loss of biological components or capabilities was responsible for the narrowing of cellular potential. By implication, it seemed that a postembryonic mammalian cell should never be able to reverse course and return to an embryonic state. The exceptions were the germ cells (eggs and sperm), which still had the potential to retrace normal development only after combining with each other.

Goal-oriented unidirectional development was easily accepted as scientific dogma because it aligns neatly with traditional Judaeo-Christian-derived religious doctrine, which permeates Western culture. As recently as 2002, Princeton professor Robert George - a defender of strict Catholicism and member of President Bush's Council on Bioethics - claimed the mantle of science when he wrote that the direction of a human embryo's growth "is not extrinsically determined, but is in accord with the genetic information within it ... It is clear that from the zygote stage forward, the major development of this organism is controlled and directed from within, that is, by the organism itself" (George's emphases). Consequently, according to George and others on the council and in the Bush administration, human zygotes and blastocysts (newly fertilized embryos that have just started to divide) are "already living human beings" deserving of protection from the murderous pursuits of biomedical scientists. Perhaps George would come to realize how outdated his views of embryology are if he read Ann Parson's book (and then again, perhaps not).

In the winter of 1953, Leroy Stevens was searching for morphological differences among inbred mice at the Jackson Laboratory in Bar Harbor, Maine, when he chanced upon the observation of an enlarged testicle in about $1 \%$ of adult males of the 129 strain. The cause of the enlargements was an inde-

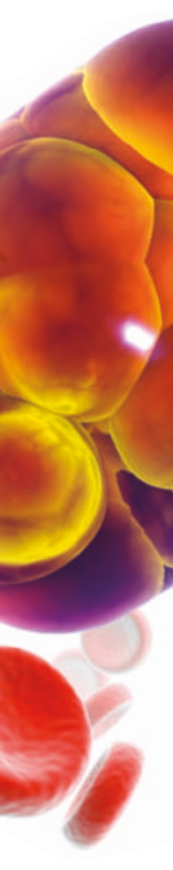

pendently growing mass of a type previously found only in human patients. It was called a teratoma because of its monster-like characteristics. Human teratomas are typically covered with skin and hair, and contain a bizarre diversity of tissues and organs normally found in other parts of the adult body, including synaptically connected neurons, muscle, beating heart tissue, bone, teeth and sometimes eye-like entities or whole limbs. Stevens realized that the 129 strain's predisposition to develop teratomas gave him a unique tool for tackling the mystery of their origin, which could provide insight into normal developmental processes.

Two years and 17,000 animals later, Stevens had dissected his way back through younger and younger mice, and ultimately fetuses, to discover that random genitalridge cells occasionally flew off-course and developed like the innards of early embryos before exploding into teratomas. In other strains, females were predisposed to teratoma formation. Ovarian cells morphed, by themselves, into an organism that Stevens said "looked just like a normal embryo, but then it would all get mixed up. It became disorganized and you had a tumour instead of a baby mouse." Stevens didn't think that mutant genes were the main trigger of this aberrant development, and when he placed normally fertilized embryos into unusual environments, such as the kidney capsule, they also became teratomas instead of mice.

Teratomas are not ordinary tumours. Along with their adult tissues, some contain cells that can grow and divide for years without becoming specialized. When dispersed and injected into mouse abdomens, these cells developed into "thousands of small structures resembling 5- or 6-day mouse embryos floating freely". Stevens was convinced that such "embryonic carcinoma" 